\title{
O brinquedo do parque um conceito lúdico como arte do reaproveitamento de materiais
}

\author{
Ana Luzia Ribeiro Mello \\ Arquiteta e urbanista, Mestre em Artes Visuais \\ anamelloarq@hotmail.com
}

\section{RESUMO}

Pesquisa pertinente à área de artes, gira em torno do resgate da "arte de brincar", da construção de brinquedos a partir de refugos de materiais disponíveis, mostrando a importância do reaproveitamento de materiais e objetos descartados pela cidade.

$O$ recorte da pesquisa foi direcionado a brinquedos de diferentes parques da região do município de Santo André, em São Paulo. A apresentação trouxe levantamentos destes brinquedos, sendo o objeto de análise desta pesquisa, os já existentes e disponíveis nesses parques. Foram coletadas informações de cunho teórico, às quais foram acrescentadas representações em imagens explicativas fornecendo elementos que facilitaram a compreensão do teor de cada brinquedo. O levantamento descritivo do material fornece alguns elementos básicos da área de recreação, tais como: raio de abrangência, vocação, características do equipamento, distribuição dos brinquedos $e$ as possibilidades de acoplamento entre eles. A abordagem está relacionada a materiais e técnicas construtivas para reaproveitamento de brinquedos existentes, voltados para o ambiente do parque, abrangendo as seguintes etapas:

1‥ Observação: Estudar a criança (desafios, habilidade, escaladas, imaginação, sensações...).

2‥ Técnica: tecnologia apropriada.

3‥ Conceito: reaproveitamento de materiais.

4‥ Linguagem: essência arquitetônica, cor, textura, design, relação, proporção e arte.

Palavras-chave: brinquedo, parque, espaço público, reaproveitamento, refugo.

\begin{abstract}
Research pertinent to the arts area, revolves around the rescue of the "art of playing", the construction of toys from the scrap of available materials, showing the importance of reusing materials and objects discarded by the city. The research focus was headed to toys from different playground areas in the region of the city of Santo André in São Paulo. The presentation brought surveys of these toys, being the object of analysis of this research, the ones already existing and available in these playground areas. Theoretical information was collected, to which representations in explanatory images were added, thus providing elements that facilitated the understanding of each toy content. The descriptive survey of the material provides some basic elements in the recreation area, such as: range of coverage, vocation, equipment features, distribution of toys and the possibilities of coupling among them. The approach is related to materials and construction techniques for reusing existing toys, aimed to the park environment, covering the following steps:

$1^{\text {st }}$ Observation: Study the child (challenges, skill, climbing, imagination, sensations ...).

$2^{\text {nd }}$ Technique: appropriate technology.

$3^{\text {rd }}$ Concept: reuse of materials.

$4^{\text {th }}$ Language: architectural essence, color, texture, design, relationship, proportion, and art.
\end{abstract}

Keywords: toy, park, public space, reuse, residue. 